\title{
PENDIDIKAN DALAM PERSPEKTIF AL-QUR'AN DAN AL-SUNNAH : Kajian Atas Istilah Tarbiyah, Taklim, Tadris, Ta'dib dan Tazkiyah
}

\author{
Ma'zumi, Syihabudin, dan Najmudin \\ Universitas Sultan Ageng Tirtayasa, Banten \\ *E-mail: zumi.mei1970@gmail.com
}

\begin{abstract}
The purpose of this study is to identify the synthesis of education in the interpretation of thematic studies of terms containing educational connotations. This article is the result of a literary study (literature) about terms that connotes education in al-Qur'an and al-Sunnah, namely tarbiyah, taklim, tadris, ta'dib and tazkiyah. This research is library research, with a content analysis approach. This study concludes that the five terms that connote to education in their contexts describe the concept of education in a whole synthesis, which is in line with the dynamics of humanity as God's representative on earth. The five terms are identical with the term da'wah and all its connotations, which indicate that education is an accumulation of Islamic da'wah. The results of this study can be used to formulate the vision, mission and goals of all disciplines and at all levels of education, both formal and nonformal.
\end{abstract}

Keywords: Education, tarbiyah, taklim, tadris, ta'dib, and tarkiyah

\begin{abstract}
Abstrak. Tujuan penelitian ini adalab untuk mengidentifikasi sintesa pendidikan dalam interpretasi kajian tematik istilah-istilah yang tercakup dalam konotasi pendidikan. Artikel ini adalah hasil dari kajian literatur (pustaka) tentang istilab-istilah yang berkonotasi dengan pendidikan dalam al-Qur'an dan al-Sunnah, yaitu tarbiyah, taklim, tadris, ta'dib dan tąkiyah. Jenis penelitian kepustakaan (library research), dengan pendekataan content analysis (kajian isi). Penelitian ini menyimpulkan bahwa kelima istilah yang berkonotasi dengan pendidikan tersebut dalam konteksnya masing-masing mendeskripsikan konsep pendidikan dalam sintesa yang utuh, yang searah dengan dinamika kemanusiaan sebagai wakil Tuhan di muka bumi. Kelima istilah tersebut identik dengan istilah dakwah dan selurub konotasinya, yang menunjukkan bahwa pendidikan merupakan akumulasi dari dakwah Islam. Hasil dari kajian ini dapat digunakan untuk merumuskan visi, misi dan tujuan dari segala disiplin keilmuan dan pada seluruh jenjang pendidikan, baik. formal maupun nonformal.
\end{abstract}

Kata Kunci: Pendidikan, tarbiyah, taklim, tadris, ta'dib, dan tąkiyah 


\section{PENDAHULUAN}

Wahyu pertama, Q.S. al-'Alaq: 15, mengilustrasikan bahwa Islam adalah anti kebodohan, amti kedzaliman dan anti monopoli, sebagai musuh utama manusia. Ayat ini menjadi penggerak utama dalam mencapai tujuan pendidikan yaitu membentuk manusia yang cerdas dan berkarakter Qur'any (pemberdaya alam lingkungannya dan mengabdikan diri kepada Allah swt). Ayat inipun membangun harapan untuk mewujudkan masyarakat yang progresif, berkontribusi dalam membangun peradaban yang bermartabat. Namun, terjadi perdebatan hangat para pakar atau ilmuwan terkait dengan konsep pendidikan. Peran pendidikan untuk melahirkan sebuah generasi tidak bisa dicapai tanpa melalui konsep yang benar. jika kita menerima teori ilmiah empiris sebagai sebuah paradigma dalam teori pendidikan, berati kita telah meninggalkan konsep metafisika (Abdullah, 2007: 21). Metode ilmiah dalam membangun sebuah teori harus dapat dibuktikan secara empiris untuk dapat dijadikan dasar dalam menyusun sebuah teori termasuk di dalamnya teori pendidikan.

Dalam khazanah bahasa Arab, istilah pendidikan secara populer diterjemahkan dengan beberapa istilah, yaitu tarbiyah, ta'lim, tadris, ta'dib, dan tazkiyah. Istilah tarbiyyah adalah istilah yang paling populer dan paling banyak digunakan. Istilah-istilah ini, dengan pendekatan semantik, dikaji dari aspek kebahasaan, aspek penggunaannya secara leksikal dan penggunaannya dalam berbagai konteksnya dalam al-Qur'an alSunnah.

Pendidikan menjemput ilham Allah dan menuntun untuk melakukan kreatifitas dengan melakukan serangkaian uji coba, membangun pemikiran imajinatif, sehingga kita menjadi insan merdeka yang melahirkan inovasi dan kreativitas tanpa batas. Menjadi hal yang sangat penting dan mendasar bagi para muslim untuk memahami konsep pendidikan menurut al-Qur'an dan alSunnah. Konsep dasar yang perlu untuk dikaji berawal dari definisi atau pengertian pendidikan dengan berbagai konotasinya yang disandarkan pada $\mathrm{Al}$ Qur'an dan As Sunnah. Seluruh konotasi istilah hamper pendidikan memiliki kesamaan dengan istilah dakwah Islam yang menggunakan istilah tabligh, amar ma'ruf-nabyi munkar, dan mau'idzah. Sebagaimana diagram di bawah ini:

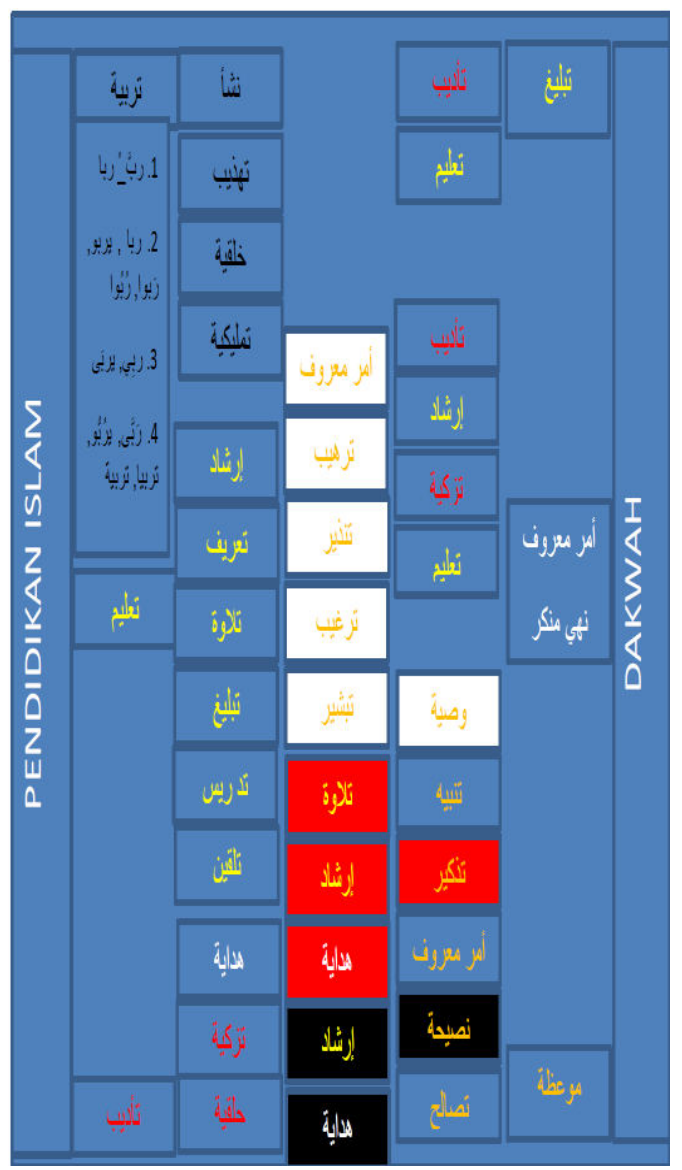

Bahwa: tarbiyah berkonotasi dengan nasy'an, tahdzib, khalqiyah, tamlikiyah; taklim berkonotasi dengan irsyad, ta'rif, tilawah, tabligh, tadris, dan talqin; ta'dib berkonotasi dengan bidayah tarkiyah dan khalqiyah. Seluruh istilah- 
istilah tersebut berkonotasi juga dengan istilah-istilah konotasi dakwah.

\section{METODE PENELITIAN}

Dalam penelitian ini penulis menggunakan jenis penelitian kepustakaan (library research), dengan prosedur penelitian sebagai berikut:

\section{A. Pendekatan Penelitian}

Model pendekataan yang digunakan dalam penelitian ini adalah content analysis (kajian isi), bersifat analisis pembahasan yang mendalam terhadap isi suatu informasi tertulis atau tercetak dalam karya-karya para Ahli Pendidikan.

B. Sumber Data

1. Sumber data primer, diperoleh langsung dari karya-karya para Ahli Pendidikan.

2. Sumber data sekunder, diperoleh buku-buku yang mendukung penulis untuk melengkapi isi serta interpretasi dari al-Qur'an dan al-Sunnah

\section{Fokus penelitian}

Fokus dalam penelitian ini adalah studi karya-karya para Ahli Pendidikan.

\section{Teknik Pengumpulan Data}

Pengumpulan data dengan menghimpun pemikiran para ahli Pendidikan tentang tarbiyah, ta'lim, tadris, ta'dib, dan tarkiyah. untuk memahami data-data tersebut dapat digunakan teknik content analysis dalam perspekti al-Qur'an dan alSunnah.

\section{E. Analisis Data}

Analisis meliputi penyajian data dan pembahasan dilakukan secara kualitatif konseptual. Analisis data harus selalu dihubungkan dengan konteks dan konstruk analisis. Konteks berkaitan dengan hal-hak yang berhubungan dengan struktur karya, sedangkan konstruk berupa bangunan konsep analisis. Analisis konten kajian kualitatif dengan ranah konseptual. dimulai dengan membaca, mencatat (mengumpulkan data), menidentifikasi, menyusunnya dalam satuan-satuan sesuai urutan pola berpikir, kemudian menganalisis hingga pada kesimpulan.

\section{HASIL PENELITIAN DAN PEMBAHASAN}

\section{A. Tarbiyyah}

Dalam literatur-literatur berbahasa Arab kata tarbiyah mempunyai banyak definisi yang intinya sama yaitu mengacu pada proses pengembangan potensi yang dianugrahkan pada manusia. Definisidefinisi itu antara lain sebagai berikut:

Tarbiyyah adalah proses pengembangan dan bimbingan jasad, akal dan jiwa yang dilakukan secara berkelanjutan sehingga mutarabbi (anak didik) bisa dewasa dan mandiri untuk hidup di tengah masyarakat (Thabary, 1988): 67).

Tarbiyyah adalah kegiatan yang disertai dengan penuh kasih sayang, kelembutan hati, perhatian bijak dan menyenangkan; tidak membosankan (alMaraghy, Tafsir al-Maraghy, juz V, (Beirut: Daar al-Fikr, 1871: 34).

a. Tarbiyyah adalah mendidik anak melalui penyampaian ilmu, menggunakan metode yang mudah diterima sehingga ia dapat 
mengamalkannya dalam kehidupan sehari-hari (al-Ashqalany, 2010: 243).

b. Tarbiyyah adalah yang mencakup pengembangan, pemeliharaan, penjagaan, pengurusan, penyampaian ilmu, pemberian petunjuk, bimbingan, penyempurnaan dan perasaan memiliki terhadap anak didik (Al-Maraghy, 97).

Para ahli memberikan definisi tarbiyah, bila diidentikkan dengan al-rabb adalah sebagai berikut:

a. Menurut al-Quturbi, bahwa; arti arrabb adalah pemilik, tuan, maha memperbaiki, yang maha pengatur, yang maha mengubah, dan yang maha menunaikan (al-Qurthuby, tth: 15).

b. Menurut Louis al-Ma'luf ar-rabb berarti tuan, pemilik, memperbaiki, perawatan, tambah, dan mengumpulkan (Ma'luf, 1960: 6).

Menurut Fahru Razi, ar-rabb merupakan fonem yang seakar dengan al-tarbiyah yang mempunai arti attanwiyah yang berarti (pertumbuhan dan perkemba-ngan) (al-Razi, t.th: 12).

c. Al-Jauhari yang dikutip oleh alAbrasy memberi arti kata tarbiyah dengan rabban dan rabba dengan memberi makan, memelihara dan mengasuh (Zuhairini, 1950: 17).

Dari pandangan beberapa pakar tafsir tersebut, kata dasar ar-rabb, mempunyai arti yang luas antara lain; memiliki, menguasai, mengatur, memelihara, memberi makan, menumbuhkan, mengembangkan dan berarti pula memanaje ${ }^{1}$. Konsep tarbiyyah merupakan

${ }^{1}$ Q.S. al-Fatihah: 2, bahwa Allah itu Rabb semesta alam, yaitu sebagai pencipta, penjaga, yang mengadakan fasilitas hidup, salah satu konsep pendidikan Islam yang penting. Menurut Al-Attas (Naquib, : 65), secara semantik istilah tarbiyyah tidak tepat dan tidak memadai untuk membawakan konsep pendidikan dalam pengertian Islam, sebagaimana dipaparkan, bahwa: Istilah tarbiyyah yang dipahami dalam pengertian pendidikan sebagaimana dipergunakam di masa kini, tidak secara alami mengandung unsurunsur esensial pengetahuan, intelegensi dan kebajikan yang pada hakikatnya merupakan unsur-unsur pendidikan yang sebenarnya. Jika sekiranya dikatakan bahwa suatu makna yang berhubungan dengan pengetahuan disusupkan dalam konsep rabba, maka makna tersebut mengacu pada pemilikan pengetahuan (penulis: pada aspek manajerial) dan bukan penanamannya. Konsep tarbiyyah merupakan proses mengurus dan mengatur supaya perjalanan kehidupan berjalan dengan lancar.

Kata al-rabb juga berasal dari kata tarbiyyah yang berarti mengantarkan sesuatu kepada kesempurnaan secara bertahap, sebagaimana Q.S. al Syu'ara: 18, "Fir'aun menjawab: "Bukankah kami telah mengasubmu di antara (keluarga) kami, waktu kamu masih kanak-kanak dan kamu tinggal bersama kami beberapa tabun dari umurmu". Ini menegaskan pada proses pengasuhan atau membesarkan. Proses tarbiyah tidak mencakup langsung keterlibatan ilmu sebagai aspek penting dalam pendidikan. Proses pengembangan (penumbuhan) diri sebagai pengembangan yang bersifat materi, pada dimensi biologis (meterialistik) dan bersifat kuantitatif (aturan, fasilitas dan kondisi).

pemilik, dan pengatur. Demikian pula sebagaimana dalam QS. al-Isra' ayat 24 'Dan rendabkanlah dirimu terbadap mereka berdua dengan penuh kesayangan dan ucapkanlab: "Wabai Tubanku, kasibilah mereka keduanya, sebagaimana mereka berdua Telah mentarbiyah Aku waktu kecil”. 


\section{B. Taklim}

Taklim berasal dari akar kata

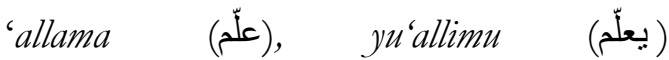
dan ta'lim (نعليم). Yu'allimu diartikan dengan mengajarkan, dan ta'lim artinya pengajaran (instruction; teach-of). M. Thalib mengatakan bahwa ta'lim memiliki arti memberitahukan sesuatu kepada seseorang yang belum tahu (Thalib, 1996: 16).

Dan mu'allim atau pengajar yang berarti orang yang melakukan pengajaran. ${ }^{2}$ Sebagaimana hadits nabi Muhammad SAW.:

اعلمو ا بطا عة الله واتقو المعا صى الله

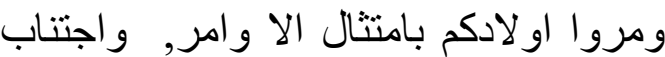

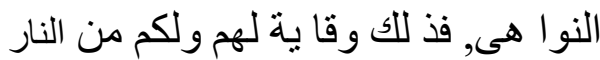
Artinya: "Ajarkanlah mereka untuk ta'at kepada Allah dan takut berbuat maksiat kepada Allah serta surublah anak-anak kamu untuk menaati perintah-perintah dan menjaubi larangan-larangan. Karena yang demikian itu akan memelibara mereka dan kamu dari api neraka"

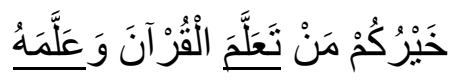

Artinya: "sebaik-baik kamu adalah orang yang mempelajari al-Qur'an dan mengajarkannya”. (H.R. al-Bukhary)

Taklim secara umum hanya terbatas pada pengajaran (proses transfer ilmu pengetahuan) dan pendidikan kognitif semata-mata (proses dari tidak tahu menjadi tahu). ${ }^{3}$ Beberapa ahli Pendidikan mendefinisikan taklim, sebagai berikut:

${ }^{2}$ H.R. Thurmudzy dan Darimi dari Abu Umamah al-Bahily ra.

3كنا نعلم او لادنا مغازي رسول الله صلى الله عليه وسلم كما

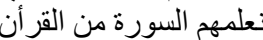

Dari perkataan Sa'ad bin waqash, "memberi makna anak-anak yang tidak tabu tentang riwayat Rasulullah, diajarkan sebingga menjadi tabu". a. Abdul Fatah Jalal, mendefinisi-kan taklim sebagai proses pemberi pengetahuan, pemaha-man, pengertian, tanggung jawab, dan penanaman amanah,.... taklim menyangkut aspek pengetahuan dan keterampilan yang dibutuhkan seseorang dalam hidup serta pedoman perilaku yang baik. Taklim merupakan proses yang terus menerus diusahakan semenjak dilahirkan, sebab manusia dilahirkan tidak mengetahui apa-apa, tetapi dia dibekali dengan berbagai potensi yang memper-siapkannya untuk meraih dan memahami ilmu pengetahuan serta memanfaatkannya dalam kehidupan (Jalal, 1977: 32).

b. Menuruit Rasyid Ridho, taklim adalah proses transmisi berbagai ilmu pengetahuan pada jiwa individu tanpa adanya batasan ketentuan tertentu. Definisi ini berpijak pada Firman Allah yang berbunyi:

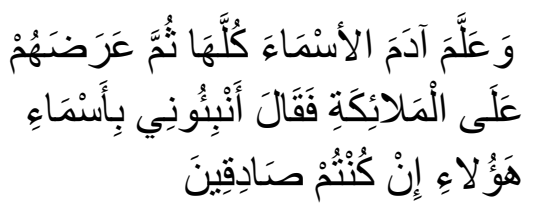

Artinya: " Dan dia mengajarkan kepada Adam nama-nama (bendabenda selurubnya), kemudian mengemukakannya kepada para malaikat. Kemudian Allab berfirman: "Sebutkanlab kepada-Ku nama-nama itu jka kamu memang orang-orang yang benar. (Q.S. al-Baqarah: 31) (Ridho, 1373: 42).

Rasyid Ridho memahami kata 'allama' sebagai proses transmisi

TARBAWY: Indonesian Journal of Islamic Education - Vol. 6 No. 2 (2019) | 198 
yang dilakukan secara bertahap sebagaimana Adam menyaksikan dan menganalisis asma yang diajarkan Allah kepadanya. taklim mencakup fase bayi, anak-anak, remaja, dan orang dewasa... (Ridho, 1373 H: 42).

c. Muhammad Naquib al-Attas, mengartikan taklim dengan pengajaran. Bila taklim disinonimkan dengan tarbiyah, maka taklim mempunyi arti pengenalan tempat segala sesuatu dalam sebuah sistem. Menurutnya ada hal yang membedakan antara tarbiyah dengan taklim, yaitu ruang lingkup taklim lebih umum daripada tarbiyah, karena tarbiyah tidak mencakup segi pengetahuan dan hanya mengacu pada kondisi eksistensial, yang mengacu pada segala sesuatu yang bersifat fisik mental (Naquib, 17).

d. Menurut Muhammad Athiyah alAbrasy, taklim lebih khusus dibandingkan dengan tarbiyah, karena taklim hanya merupakan upaya menyiapkan individu dengan mengacu pada aspek-aspek tertentu saja, sedankan tarbiyah mencakup keseluruhan aspekaspek pendidikan (al-Abrasy, 1968: 32).

Beberapa ayat terkait dengan kata taklim dalam pengertian instruction antara lain: Q.S. alJum'ah: 2, Q.S. al-Baqarah: 151, Q.S. al-Rahman: 1-4, Q.S. Yasin: 69, Q.S. al-Syu'ara: 49, Q.S. Thaha: 71, Q.S. al-Kahfi: 66, Q.S. Yusuf:: 6 dan 37, 68 dan 101, Q.S. alNisa': 113, QS. Ali Imran: 17 dan 48, Q.S. al-Baqarah: 30, 31, 129,
239, Q.S. al-Maidah: 4 dan Q.S. alHujurat: 16.

Penggunaan kata 'allama-ta'lim juga didapatkan pada hadits-hadits berikut:

"Barang siapa yang mengajarkan suatu ilmu maka dia memperoleb pabala orang yang mengamalkannya." (HR. Ibn Majah).

"Diantara amal dan kebaikan yang menyusul seseorang sesudab matinya adalah: ilmu yang dia ajarkan dan sebarluaskan, ..." (HR. Ibn Majah, Baihaqi dan Khuzaimah).

Sa'ad bin Abu Waqqash r.a berkata:

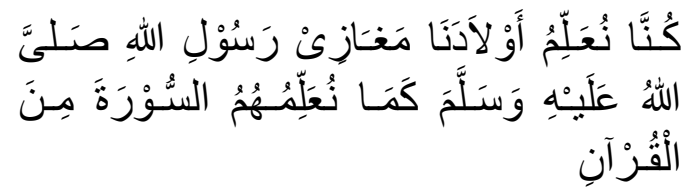

"Kami mengajar anak-anak kami riwayat bidup Rasulullah SAW Seperti kami mengajarkan satu surat dari Al Qur'an"

اعملو ا بطاعة الله و اتقوا معاصى الله و مروا اولادكم بامنتال الاوامر, و اجنة إنتاب النواهى, فذاللك و قاية لهم و لكم من النّار "Ajarkanlah mereka untuk ta'at kepada Allah dan takut berbuat maksiat kepada Allah serta surublab anak-anak kamu untuk menaati perintah-perintah dan menjaubi larangan-larangan. Karena itu akan memelihara mereka dan kamu dari api neraka" (HR. Tirmidzi dan Darimi).

Umar ibn Khatab berkata:

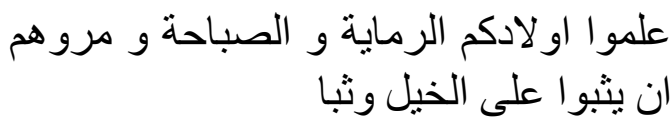

"Ajarkanlah memanah dan berenang kepada anak-anak kamu, dan surublab mereka melompat keatas kuda dengan sekali lompatan" 
من دخل مسجدنا هذا ليعلّم خير ا او ليتعلّم كان كا المجاهد في سبيل الله

"Barang siapa masuk masjid kami ini untuk tujuan mengajarkan kebaikan atau untuk belajar, maka dia bagaikan orang berperang di jalan Allab”( HR. Ibn Majah).

Dari Abu Hurairah, Rasulullah bersabda,

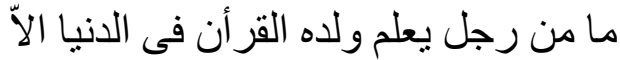

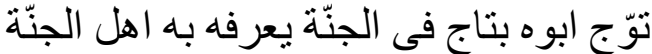

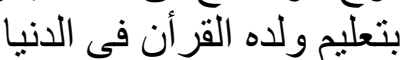

"Tidaklah seseorang mengajarkan Al Qur'an kepada anaknya di dunia kecuali ayabnya pada hari kiamat dipakaikan mabkota surga. Abli surgamengenalinya dikarenakan dia mengajari anaknya AlQur'an di dunia."

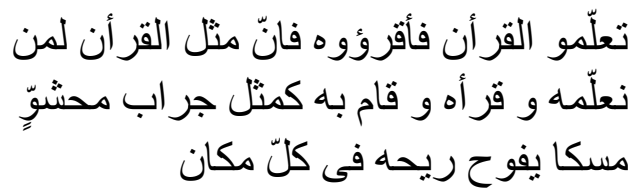

"Belajarlah Al Qur'an, lalu bacalah. Sesunggubnya perumpamaan Al Qur'an bagi orang yang mempelajari, membaca dan beribadah malam dengannya bagaikan tempat yang dipenubi minyak kesturi yang semerbak bau harumnya di setiap tempat" (HR. Thabrani).

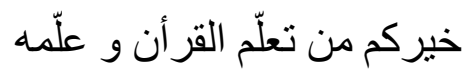

"Sebaik-baik kamu adalah orang yang mempelajari al-Qur'an dan mengajarkannya" (HR. Bukhari).

ما اجتمع قوم فى بيت من بيوت الله يتعلّمون

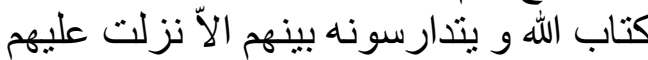
السكينة و غشيتهم الرحمة و ونّة ونتهم الملائكة

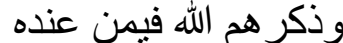

"Sekelompok masyarakat tidak berkumpul di masjid mempelajari kitab Allab dan bertadarrus diantara mereka, kecuali turun kepada mereka ketenangan, mereka diliputi rakhmat, dikerumuni malaikat dan Allah membanggakan mereka kepada makbluk. bidup disisinya" (HR. Muslim).

Berdasarkan beberapa ayat dan beberapa hadts tersebut, istilah ta'lim menunjukkan bahwa ilmu yang bisa untuk dialihkan meliputi semua ilmu termasuk diantaranya sihir. Sehingga memang istilah tersebut lebih dekat pada pengajaran bukan pendidikan, karena pendidikan dalam pengertian Islam tentu saja harus mengarah pada manusia yang lebih baik, sesuai peran dan fungsinya menurut al-Qur'an dan al-Sunnah. Dalam konsep ta'lim, Allah adalah "Guru" para nabi dan manusia. Menurut AzZajjaj, taklim merupakan cara Allah mengajarkan para nabi dan umat manusia tentang "ilmu pengetahuan" dan "teknologi", sebagaimana dipahami dalam petikan ayat: "Dan telah Kami ajarkan kepada Daud membuat baju besi untuke kamu, guna memelihara kamu dalam peperanganmu, maka hendaklah kamu bersyukur (kepada Allab)" (Q.S. al-Anbiya: 80).

Ilmu pengetahuan menurut Islam merupakan landasan kuat bagi keimanan dan sekaligus pedoman amal dalam meningkatkan kualitas hidup manusia untuk memperoleh ridha Allah SWT. Konsep taklim secara filosofis dalam alQur'an digunakan khusus untuk menunjukkan ilmu pengetahuan dan teknologi yang dapat diulang dan dikembangkan, sehingga menghasilkan pengaruh ke arah ketinggian spiritaul pada diri muta'allim. Ilmu pengetahuan dan teknologi dapat digali melalui budaya baca dan budaya tulis - bukan sekedar budaya lisan dan menghapal - dan dapat dikembangkan dengan semangat kritis intelectual curiosity dan kekuatan creative imagination melalui aktifitas intidzar (Q.S. al-'Alaq: 1-5). Proses pendidikan dalam 
kansep taklim tidak dapat berdiri sendiri. Ia merupakan rangkaian dari aktivitas tilawah, ta'lim, dan tarkiyah, sebagaimana informasi Allah berikut:

"Ya Tuban kami, utuslab untuk mereka seorang Rasul dari kalangan mereka, yang akan membacakan kepada mereka ayat-ayat Engkau, dan mengajarkan kepada mereka alKitab (al-Qur'an) dan Hikmah (as-Sunnah) serta mensucikan mereka. Sesunggubnya Engkaulah yang Maha Perkasa lagi Maha Bijaksana." (Q.S. al-Baqarab: 129).

Secara peadagogis, aktifitas tilawah adalah membacakan ayat-ayat Allah secara tartil dan fasih, dengan tujuan memberikan kabar gembira (tabsyir) dan peringatan (tanzir), serta mengingatkan mereka yang lupa (tadzkir/tanbih lil ghafilin); lalu dilanjutkan dengan aktifitas ta'lim, yakni menjelaskan esensi kandungan al-Qur'an dan al-Sunnah tentang halal-haram dengan segala konseksewensi yang melekat, yang halal dengan kemaslahatannya dan yang haram dengan segala kemafsadatan yang ditimbulkannya; menafsirkan informasi secara kreatif dan produktif.

Makna tilawah ini sebangun dengan makna tabligh (menyampaikan suatu informasi secara transparan, terbuka, dan lugas); sedangkan makna ta'lim sebagun dengan makna tabyin, sebagaimana firman Allah:

"Kami tidak mengutus seorang Rasul pun, melainkan dengan bahasa kaumnya, supaya ia dapat memberi penjelasan dengan terang kepada mereka..." (Q.S. Ibrahim: 4).

Proses ta'lim atau tabyin tersebut diharapkan berpengaruh pada jiwa para pembelajar. Mereka dapat bertindak sesuai pengetahuan mereka tentang halal-haram, dengan kesadaran tazkiyah (internalisasi nilai) dan ishalah (eksternalisasi nilai). Tazkiyah berarti membebaskan diri dari segala perbuatan keji dan munkar sambil menghiasi diri dengan sifat-sifat terpuji sehingga terpancar pesona pribadi insan yang adiluhung; sedangkan ishlah berupa keberanian menegakkan amar ma'rif nabi munkar, terpanggil untuk membebaskan masyarakat dari segala penyakit sosial, memelihara ukhuwah islamiyah, peka dan memiliki komitmen untuk senantiasa memihak kepada si tertindas dan sungguh-sungguh mereformasi tatanan sosial-ekonomi-politik yang tak berkeadilan. Proses $t a^{\prime} l i m$ ini dapat ditarik dari makna ayat berikut:

"Orang-orang yang mengikuti Rasul, Nabi yang ummi, yang (namanya) mereka dapati tertulis di dalam Taurat dan Injil yang ada di sisi mereka, yang menyurub mereka mengerjakan yang ma'ruf dan melarang mereka dari mengerjakan yang munkar dan menghalalkan bagi mereka segala yang baik dan mengharamkan bagi mereka segala yang buruk dan melepaskan dari mereka bebanbeban dan belenggu-belengguyang ada pada mereka. Maka orang-orang yang beriman kepadanya, memuliakannya, menolongnya dan mengikuti cahaya yang terang yang diturunkan kepadanya (al-Qur'an), mereka itulah orangorang yang beruntung." (Q.S. al-A'raf: 157).

Rasa ingin tahu dan pencarian kebenaran itu dilakukan melalui eksplorasi dan ekspresi sensoris (panca indra) secara konstan. Tugas pendidik adalah membantu anak dalam merekonstruksi pengetahuan baru dengan memanfaatkan pengalaman dan pengetahuan awal yang telah dimilikinya. Pendidik melatih kognitif anak merumuskan gagasan menjadi konsep yang lebih sistematis, logis, dan rasional.

\section{Tadris}


Tadris dari akar kata daras - darras, artinya pengajaran, adalah upaya menyiapkan murid (mutadaris) agar dapat membaca, mempelajari dan mengakaji sendiri, yang dilakukan dengan cara mudarris membacakan, menyebutkan berulang-ulang dan bergiliran, menjelaskan, mengungkapkan dan mendiskusikan makna yang terkandung didalamnya sehingga mutadrris mengetahui, mengingat, memahami, serta mengamalkannya dalam kehidupan sehari-hari dengan tujuan mencari ridho Allah (definisi secara luas dan formal). Al-Juzairi memakai tadarrsu dengan membaca dan menjamin agar tidak lupa, berlatih dan menjamin sesuatu. Menurut Rusiadi dalam tadris tersirat adanya mudarris. Mudarris berasal dari kata darasa-yadrusu-darsan-durusan-dirasatan yang artinya terhapus, hilang bekasnya, mengahapus, melatih dan mempelajar. Artinya guru adalah orang yang berusaha mencerdaskan peserta didiknya, menghilangkan ketidaktahuan atau memberantas kebodoha, serta melatih keterampilan peserta didik sesuai dengan bakat dan minatnya. ${ }^{4}$ Mudarris adalah orang yang memiliki kepekaan intelektual dan informasi serta memperbaruhi pengetahuan dan keahliannya secara berkelanjutan, dan berusaha mencerdaskan peserta didiknya, memberantas kebodohan mereka, serta melatih keterampilan sesuai dengan bakat, minat, dan kemampuannya ${ }^{5}$

Tadris adalah suatu bentuk kegiatan yang dilakukan oleh mudarris untuk membacakan dan menyebutkan suatu kepada mutadarris (murid) dengan berulang-ulang dan sering. Tadris

${ }^{4}$ Rusiadi, Metodologi Pembelajaran Agama Islam, Cet. Ke II, (Jakarta: Sedaun, 2012), hal. 13

5 Yayan Ridwan, Ilmu Pendidikan Islam, Cet. Ke I, (Jakarta: Sedaun, 2011), 65 bertujuan agar materi yang dibacakan atau disampaikan itu mudah dihapal dan diingat. Ia merupakan kegiatan pewarisan kepada murid dari para leluhurnya.

a. Kegiatan dalam tadris tidak sekedar membacakan tau menyebutkan materi, tetapi juga disertai dengan mempelajari, mengungkap, menjelaskan, dan mendiskusikan isi dan maknanya.

b. Tadris adalah suatu upaya menjadikan dan membelajarkan murid (mutadarris) supaya mau membaca, mempelajari, dan mengakaji sendiri.

c. Dalam tadris, seorang murid (mutadarris) diharapkan mengetahui dan memahami benar yang disampaikan oleh mudarris (guru) serta dapat mengamalkan di dalam kehidupan sehari-hari.

d. Tadris dilakukan dengan niat beribadah kepada Allah SWT dan mendapat ridhaNya.

e. Kegiatan belajar dalam tadris bisa berlangsung dengan cara saling bergantian atau bergilirian, yaitu sebagian membaca sebagian lainnya memperhatikan dengan saing mengoreksi, emmbenarkan kesalahan lafal yang dibaca sehingga terhindar dari kekeliruan dan lupa.

f. Tadris menunjukan kegiatan yang terjadi pada diri manusia dalam arti yang umum.

Tadris merupakan taklim secra mendalam dan dengan kajina khusus AlKitab. Makna kata tadris dapat kita baca dalam pertikan firman Allah berikut:

"Adakah kamu kamu mempunyai sebuah kitab (yang diturunkan Allab) yang kamu membacanya?" (Q.S. al-Qalam: 37) 
"Dan Kami tidak pernah memberikan kepada mereka kitab-kitab yang mereka baca..." (Q.S. Saba':44)

"Hendaklah kamu menjadi orang-orang rabbani, karena kamu selalu mengajarkan alKitab dan disebabkan kamu tetap mempelajarinya." (Q.S. Ali Imran: 79)

Kata tadris berkonotasi pada proses mempelajari al-Kitab (atau alQur'an). Kata ini telah diserap dalam khazanah bahasa dan budaya bangsa dengan istilah ngeder's, atau tadarusan. Ngeder's itu belajar dengan cara mengulang, menghapal, dan melestarikan ide, nilai, dan ajaran yang bersifat absolut. Tempat untuk mempelajari kitab suci AlQur'an itu disebut madrasah. Dari sisi bahasa Arab, madrasah adalah bentuk isim makan dari kata tadris yang berarti tempat ngeders. Meskipun demikian, penggunaan kata madrasah di Indonesia sama sekali berbeda dengan penggunaannya dalam tradisi Islam klasik. Dalam bahasa Indonesia modern, madrasah menunjuk pada lembaga pendidikan dasar dan menengah orang Islam untuk mempelajari bahasa Arab dan isi kandungan al-Qur'an serta ilmu keislaman lainnya secara klasikal. Dalam sejarah keemasan Islam klasik, madrasah merujuk pada suatu institusi pendidikan tinggi yang secara luas mulai dikenal sejak abad ke-5/11, seperti Madrasah Nidzamiyah. Madrasah juga berarti madzhab (aliran pemahaman keagamaan tertentu), yang kemudian diajarkan di madrasah. Madrasah pada umumnya menganut madzhab tertentu para pendirinya, khususnya dalam madzhab syafi'i. Pendidik di madrasah Perguruan Tinggi Ilmu Hukum - itu disebut Mudarris, meliputi: Syaikh (guru besar), Naib (asisten dosen dengan kualifikasi setara guru besar), Mu'id (mahasiswa pascasarjana senior yang dipercaya guru besar), dan Mufid (mahasiswa reguler yang dipercaya syeikh membantu mahasiswa pemula) dan Muthalib (mahasiswa) (Asari, 1994: 39), yang memiliki perlengkapan akademis tingkat tinggi (Tim Dosen, 2019: 52), mempertahankan kelangsungan hidupnya dan meraik sukses (Buzan, 2005: 130).

\section{Ta'dib}

Ta'dib berasal dari kata addaba (إدبّ), yuaddibu (بأَّب) dan ta'dib (نأديب), biasa diartikan dengan 'allama atau mendidik. Addaba (أدّب) diterjemahkan oleh Ibnu Manzhur merupakan padanan kata allama dan oleh Azzat dikatakan sebagai cara Tuhan mengajar Nabi-Nya, sehingga AlAttas mengatakan bahwa kata addaba (ta'dib) mendapatkan rekanan konseptualnya di dalam istilah ta'lim. AlAttas memaknai pendidikan dari hadith,

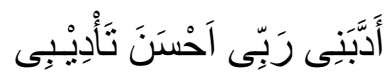

"Tuhanku (Allah) telah mendidikku dengan pendidikan yang terbaik",

Selanjutnya Al Attas menyampaikan(Al-Attas, 61), "Dalam pendefinisian kita tentang 'makna', kita katakan bahwa 'makna' adalah pengenalan tempat segala sesuatu dalam sebuat sistem. Karena pengetahuan terdiri dari sampainya, baik dalam arti bushul dan wushul, makna di dalam dan oleh jiwa, maka kita definisikan 'pengetahuan' sebagai pengenalan tempat-tempat yang tepat dari segala sesuatu di dalam penciptaan sedemikian rupa, sehingga hal ini membawa kepada pengenalan tentang tempat yang tepat dari Tuhan dalam tatanan wujud dan keperiadaan.

6 Lihat Jami' al-Ahadits wa al-Marasil, nomor $780-781$ 
Agar pengetahuan bisa dijadikan 'pengetahuan', kita masukkan unsur dasar pengakuan di dalam pengenalan, dan kita definisikan kandungan pendidikan ini sebagai pengenalan dan pengakuan tempat-tempat yang tepat dari segala sesuatu di dalam keteraturan penciptaan sedemikian rupa, sehingga hal ini membimbing ke arah pengenalan dan pengakuan tempat-tempat Tuhan yang tepat dalam tatanan wujud dan kepriadaan. Kemudian kita definisikan pendidikan, termasuk pula proses pendidikan, sebagai pengenalan dan pengakuan yang secara berangsur-angsur ditanamkan dalam manusia tentang tempat-tempat yang tepat dari segala sesuatu di dalam tatanan penciptaan sedemikian rupa, ini membimbing ke arah pengenalan dan pengakuan tempat Tuhan yang tepat di dalam tatanan wujud dan keperiadaan."

Al-Attas, mengartikan kata addaba (أدّب) secara generik (Penulis: kekhasan) adalah undangan kepada suatu perjamuan (al-Attas, 57). Pengunaan ta'dib lebih cocok untuk pendidikan islam, konsep inilah yan diajarkan oleh Rasul. Ta'dib berarti pengenalan, bimbingan, pengakuan yang secara berangsur-angsur ditanamkan kepada manusia tentang segala sesuatu dalam tatanan penciptaan, sehingga membimbing kearah kesopanan, keramahan, kehalusan budi pekerti , dan ketaatan terhadap kekuasaan dan keagunggan Allah. Konsep ta'dib yang digagas al-Attas ini adalah konsep pendidikan Islam yang integratif (alAttas, 1987: 90).

Abdullah Nasih Ulwan (1994: 200), mengambil hadits yang diriwayatkan oleh Thabrani dari Ali r.a. untuk menjadi dasar penting terhadap pendidikan al-Qur'an untuk anak, bahwa Rasulullah bersabda:

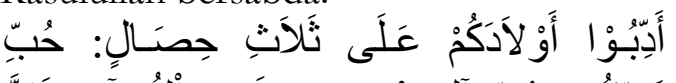

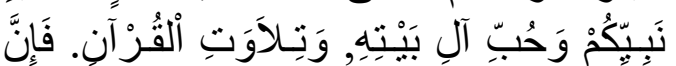

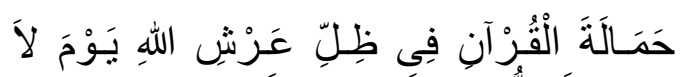

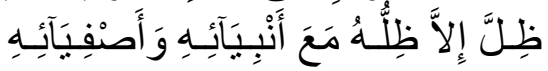

"Didiklah anak-anakmu dalam tiga hal: mencintai Nabimu, mencintai keluarga nabi, dan membaca Al Qur'an. Maka sesunggubnya yang membaca Al Qur'an berada dalam naungan Nya, bersama para Nabi dan orangorang Suci"

Istilah ta'dib dalam tradisi arab dikaitkan dengan kemuliaan dan ketinggian pribadi seseorang. Sebagaimana hadits-hadits berikut:

$$
\text { أدبّو ا او لادكم و احسنو ا ادابهم }
$$

"Didiklah anak-anak kamu dengan pendidikan yang baik." (H.R. Ibn Majjah)

علمو ا او لادكم و أهليكم الخير و

أدبو هم

"Ajarkanlah kebaikan kepada anak-anak kamu dan didiklah mereka"

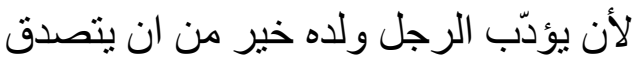

"Seorang yang mendidik anaknya itu lebih baik daripada bersedekah satu sha"

$$
\text { اكرما او لادكم و احسنو ا ادا بهم }
$$

"Muliakan anak-anak kalian dengan adab yang baik"

$$
\text { من حقّ الولد على الوالد أن يحسن ادبه و }
$$

"Diantara yang menjadi bak seorang anak atas orang tuanya adalah memperbagus adabnya dan menamakannya dengan nama yang baik"

$$
\text { ما نحل و الد ولدا افضل من ادب حسن }
$$

"Tidak ada suatu pemberian yang lebih utama yang diberikan oleh seorang ayah kepada anaknya, kecuali adab yang baik"”

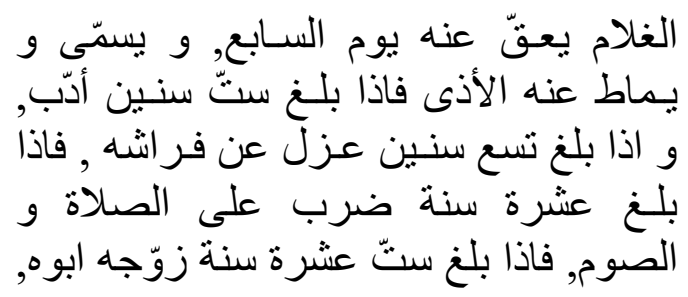




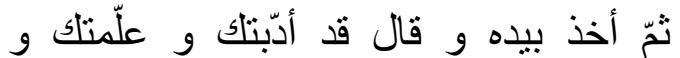

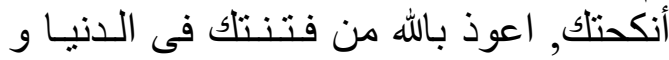

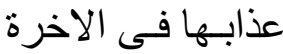
"Seorang anak diselamati pada hari ketujuh dari kelabirannya, diberi nama dan dibilangkan penyakitnya (dicukur rambutnya). Jika sudah menginjak usia enam tahun, maka ia diberi pendidikan. Jika sudah menginjak usia sembilan tabun, maka ia dipisabkan tempat tidurnya. Jika sudab menginjak usia tigabelas tabun maka ia harus dipukul bila tidak mau mengerjakan sholat dan puasa. Dan jika telab menginjak enambelas tabun, maka ayahnya boleb mengawinkan, lalu memegang anaknya itu dengan tangannya dan berkata padanya:'Aku telah mendidikmu, mengajarmu dan mengawinkanmu'. Aku berlindung kepada Allah dari fitnah (yang disebabkan ulab)mu di dunia dan dari adzab yang (disebabkan) fitnah itu di akbirat"

Menurutnya, "para pendidik terutama ayah dan ibu, mempunyai tanggung jawab besar dalam mendidik anak dengan kebaikan dan dasar-dasar moral. Mereka bertanggung jawab untuk mendidik anak-anak sejak kecil untuk berlaku benar, dapat dipercaya, istiqomah, ... (Ulwan, 1994: 189).

Konsep ta'dib adalah konsep pendidikan Islam yang komprensif, karena aspek-aspek ilmu dan proses pencapaiannya mesti dicapai dengan pendekatan tauhid dan objek-objeknya diteropong dengan pandangan hidup Islami (worldview isalm) (Al- Attas, 1995: 2). Pendekatan tauhid adalah pendekatan yang tidak dikotomis(Guttenplan, t.th.: 5-7) dalam melihat realita. Menurut alAttas, pendidikan Islam bukanlah seperti pelatihan yang akan menghasilkan spesialis. Melainkan proses yang akan menghasilkan individu baik (insan abadi), yang akan menguasai berbagai bidang studi secara integral dan koheren yang mencerminkan pandangan hidup islam (Wan Daud, 186).
Dapat disimpulkan, konsep ta'dib adalah konsep pendidilan yang bertujuan menghasilkan individu beradab, yang mampu melihat segala perseolan dengan teropong worldview Islam. Mengintengrasikan ilmu-ilmu sains dan humaniora dengan ilmu syariah. Sehingga apapun profesi dan keahliannya, syariah dan worldview Islam tetap merasuk dalam dirinya sebagai parameter utama. Individu-individu yang demikian ini adalah manusia pembentuk peradaban Islam yang bermartabat. Dalam tataran praktis, konsep ini memerlukan proses Islamisasi pengetahuan terlebih dahulu. Karena, untuk mencapai tujuan utama konsep pendidikan ini, ilmu-ilmu tidak hanya perlu diintegrasikan akan tetapi, ilmu yang berparadigma sekuler harus diislamkan basis filosofinya.

Konsep ta'dib dalam pendidikan menjadi sangat penting mengingat semakin terlihatnya gejala keruntuhan akhlak di kalangan umat Islam bukan dikarenakan mereka tidak mempunyai ilmu pengetahuan, tetapi karena mereka telah kehilangan adab. Tindak kejahatan, korupsi, penyalahgunaan kekuasaan, pembunuhan dan hal lain justru banyak dilakukan oleh pihak-pihak yang mengenyam proses pendidikan. Proses bertambahnya ilmu pengetahuan seakanakan tidak berbanding lurus bahkan tidak berhubungan dengan peningkatan akhlak yang mulia atau keimanan para mudarist.

\section{E. Tazkiyah}

Secara bahasa, tazkiyah berasal dari kata zak.ka-yuzzaki-tazkiyah yang berarti pembersihan, penyucian atau pemurnian (Hawwa, 1999: 2); dan berarti النماء yaitu tumbuh, berkah dan bertambah baik. Tazkiyah dalam arti pertama adalah membersihkan dan 
mensucikan jiwa dari sifat-sifat tercela, sedangkan arti yang kedua, adalah menumbuhkan dan memperbaiki jiwa dengan sifat- sifat terpuji. Dengan demikian tazkiyah tidak saja terbatas pada pembersihan dan penyucian diri, tetapi juga meliputi pembinaan dan pengembangan diri.

Dalam al-Qur'an kata kerja tazkiyah digunakan sebanyak dua belas kali. Subjeknya adalah Allah, dan objeknya adalah manusia. Kebanyakan ayat ini berpesan bahwa rahmat dan bimbingan Allah-lah yang mensucikan dan memberkati umat manusia mempunyai peranan penting terhadap hal itu (Chittick, 2002: 84-85).

M. Quraish Shihab dalam Tafsir Al-Mishbah menafsirkan, setelah Allah berrsumpah dengan sekian banyak hal, Allah berfirman menjelaskan apa yang hendak ditekankan-Nya dengan sumpahsumpah di atas, yaitu: Sungguh telah beruntunglah meraih segala apa yang diharapkannya siapa yang menyucikan dan mengembangkanya dengan mengikuti tuntunan Allah dan Rasul serta mengendalikan nafsunya, dan sungguh merugilah siapa yang memendamnya yakni menyembunyikan kesucian jiwanya dengan mengikuti rayuan nafsu dan godaan setan, atau menghalangi jiwa itu mencapai kesempurnaan dan kesuciannya dengan melakukan kedurhakaan serta mengotorinya (Shihab, 2002: 300). Al-Baqai, mendefinisikan bahwa tar-kiyah adalah upaya sungguh-sungguh manusia agar matahari kalbunya tidak mengalami gerhana, dan bulannya pun tidak mengalami hal serupa. Ia harus berusaha agar siangnya tidak keruh dan tidak pula kegelapannya bersinambung. Cara meraih hal tersebut adalah memperhatikan hal-hal spritual yang serupa dengan hal-hal material yang digunakan Allah bersumpah itu (Shihab, 2002: 301).

Lebih rinci lagi menurut Sayyid Qutub, tarkiyatun nafs adalah membersihkan jiwa dan perasaan, mensucikan amal dan pandangan hidup, membersihkan kehidupan dan hubungan seks, dan membersihkan kehidupan masyarakat (Qutub, 1967: 3915).

Al-Ghazali mengartikan tazkiyah berarti pembersihan diri dari sifat-sifat tercela danimaratun nafs dalam arti memakmurkan jiwa (pengembangan jiwa) dengan sifat-sifat terpuji. Tentang makna tarkiyatun nafs, para mufassir mempunyai pandangan yang berbeda-beda:

a. Tazkiyah dalam arti para rasul mengajarkan manusia, sesuatu yang jika dipatuhi, akan menyebabkan jiwa mereka tersucikan dengannya (Razi, t.th: 67).

b. Tazkiyah dalam arti mensucikan manusia dari syirik, karena syirik itu oleh Al-Quran dipandang sesuatu yang bersifat najis (AlMaraghi, t.th.: 123).

c. Tazkiyah dalam arti mensucikan dari dosa (Al-Maraghi, t.th.: 123).

d. Tarkiyah dalam arti mengangkat manusia dari martabat orang munafik ke martabat mukhlisin (Imam, t.th.: 80).

Tarkiyah dimaksudkan sebagai cara untuk memperbaiki seseorang dari tingkat yang rendah ke tingkat yang lebih tinggi didalam hal sikap, sifat, kepribadian dan karakter. Semakin sering manusia melakukan tazkiyah pada karakter kepribadiannya, semakin Allah membawanya ke tingkat yang lebih 
tinggi. Perkataan tarkiyatun ersimpul pengertian dan gagasan tentang:

a. Usaha-usaha yang bersifat pengembangan diri, yaitu usaha mewujudkan potensi-

potensi manusia menjadi kualit as-kualitas moral yang luhur (akblakul hasanab); dan

b. Usaha-usaha yang bersifat pembersihan diri, yaitu usaha menjaga dan memelihara diri dari kecenderungan immoral (akblakus sayyiah) (Effendi, 1991: 5).

Dengan demikian, tazkiyatun na $f_{s}$ adalah proses penyucian, pengembangan jiwa manusia, proses pertumbuhan, pembinaan dan pengembangan akblakul krimah (moralitas yang mulia) dalam diri dan kehidupan manusia. Dan dalam proses perkembangan jiwa itu terletak falab (kebahagiaan), yaitu keberhasilan manusia dalam memberi bentuk dan isi pada keluhuran martabatnya sebagai makhluk yang berakal budi.

Menurut Ibn Taimiyah, tarkiya adalah menjadikan sesuatu suci zat,

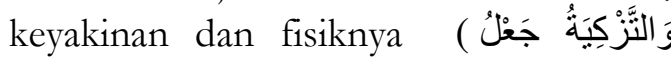

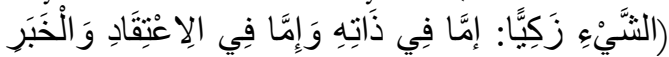
(Taimiyah, 1416: 10). dapat dikatakan bahwa pribadi yang secara fisik, mental keimanan dan kejiwaan yang baik dan bersih dari segala kelaliman dan kesyirikan, maka secara implementatif perilaku yang nampak sebagai buahnya adalah:

a. Lisan yang terkontrol (Dhabat alLisan)

Rasulullah menjadikan lurusnya lisan sebagai syarat bagi lurusnya hati, dan menjadikan lurusnya hati sebagai syarat lurusnya iman. Sebagaimana diriwayatkan dari Anas bin Malik, Rasulullah SAW bersabda:

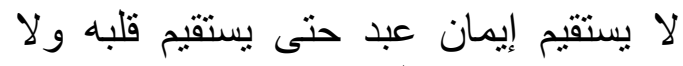
يستقيم حتى يستيم لسانه

Artinya : "Keimanan seseorang hamba tidak akan lurus sebelum lurus hatinya, dan batinya tidak akan lurus sebelum lurus lisanya" (HR Anas bin Malik).

b. Komitmen dengan Adab-adab Pergaulan (Iltizam Bi Adabil Tlaqat)

Berinteraksi dengan batasan-batasan tertentu baik secara agama maupun budaya.

Salah satu tujuan utama diutusnya Nabi Muhammad SSAW. adalah untuk membimbing umat manusia dalam rangka membentuk jiwa yang suci (suci diri dari kemusyrikan dan kekufuran) (lihat Q.S. al-Jumu'ah: 2), dan menyucikan diri dari keburukankeburukan amal perbuatan, dengan melakukan amal-amal salih. Menurut Ibnu Katsir, tazkiyah bermakna menyucikan dirinya dari dosa, keburukan dan syirik. Keberuntungan dan kesuksesan seseorang, sangat ditentukan oleh seberapa jauh ia men-tazkiyah dirinya (al-Thobari, $1420 \mathrm{H}$ : 454).

Secara umum aktivitas tazkiya mengarah pada dua kecenderungan, yaitu membersihkan jiwa dari sifat-sifat tercela, membuang seluruh penyakit hati, menjauhi kesyirikan, dan menghiasi jiwa dengan sifat-sifat terpuji.Tazkiyah merupakan misi kerasulan, yaitu upaya untuk membersikan jiwa manusia dari sesuatu yang dapat mengotori tauhid dari keyakinan yang salah, syirik, khurafat, bid'ah serta dosa-dosa lainnya yang disebabkan penyimpangan dari jalan yang lurus. Tazkiyah menjadi role value dan ultimate goal pendidikan Islam.

\section{KESIMPULAN}


Istilah ta'lim', ta'dib, tadris, dan tarbiyah jika ditinjau dari segi penekanannya terdapat titik perbedaan antara satu dengan lainny, namun apabila dilihat dari unsur kandungannya, terdapat keterkaitan yang saling mengikat, yakni dalam hal memelihara dan mendidik anak. Dalam ta'lim, titik tekannya adalah penyampaian ilmu pengetahuan yang benar, pemahaman, pengertian, tanggung jawab dan penanaman amanah kepada anak. ta'lim disini mencakup aspek-aspek pengetahuan dan keterampilan yang dibutuhkan seseorang dalam hidupnya dan pedoman perilaku yang baik. Sedangkan pada tarbiyah, titik tekannya difokuskan pada bimibangan anak supaya berdaya (punya potensi) dan tumbuh kelengkapan dasarnya serta dapat berkembang secara sempurna. Yaitu pengembangan ilmu dalam diri manusia dan pemupukan akhlak yakni pengalaman ilmu yang benar dalam mendidik pribadi.

Adapun ta'dib, titik tekannya adalah pada penguasaan ilmu yang benar dalam diri seseorang agar menghasilkan kemantapan amal dan tingkah laku yang baik. Tadris, titik tekannya adalah upaya menyiapkan anak didik tidak hanya sekedar dalam hal membaca, tetapi juga disertai dengan investasi inernalisasi nilai-nilai moral dan spritual yang diemban oleh guru untuk ditransformasikan kearah pembentukan kepribadian anak didik, mencerdaskan serta melatih keterampilan, sesuai dengan bakat, minat, dan kemampuannya. Sedangkan tazkiyah menjadi role value dan ultimate goal pendidikan Islam.

Kelima konsep diatas dalam satu kesatuan utuh proses pendidikan Islam. Kelimanya mendasari tujuan, metode, kurikulum pendidikan, dan manajemenya, yang akan menghantarkan anak didik menjadi yang "seutuhnya", sehingga mampu mengurangi kehidupan ini baik sekarang mampu akan datang dengan baik.

\section{REFERENSI}

Al-Qur'an Al-Karim

Abdullah, Abdurrahman Saleh, Educational Theory a Quranic Outlook, Terj.

Teori-teori Pendidikan Berdasarkan Al-Qur'an. Jakarta: PT Rineke Cipta, 2007.

al-Attas, Muhammad Naquib, Konsep Pendidikan Dalam Islam. Bandung: Mizan, 1988

Tafsir, Ahmad, Ilmu Pendidikan Dalam Perspektif Islam, Bandung: Rosda Karya, 1992

Al-Thabary, Abu Ja'far Muhammad Ibn Jaris, Jami'ul Bayan 'an Ta'wil ayat al-Qur'an, Beirut: Dar al-Fikr, 1988

al-Maraghy, Ahmad Musthafa, Tafsir alMaraghy, juz V, Beirut: Daar alFikr, 1871

al-Ashqalany, Al-Imam al-Hafidz Ibn Hajar, Fath al-Barr 'ala Syarh Shabih al-Bukhary, Penerjemah: Gazirah Abdi Ummah, Jakarta: Pustaka Azzam, 2010

al-Qurthuby, Ibn Abdillah Muhammad bin Ahmad al-Anshary, Tafsir alQurthuby, (al-Qahirah: Durusy, t.th.

Ma'luf, Louis, al-Munjid fi Lughah, Beirut: Daar al-Masyriq, 1960

al-Razi, Fath, Tafsir Fat al-Rasy,Teheran: Daar al-Kutub al-Ilmiyah, t.th.

Zuhairini, Metodik Pendidikan Islam, Malang: IAIN Tarbiyah Sunan Ampel Press, 1950 
M. Thalib, Pendidikan Islam Metode $30 \mathrm{~T}$, Bandung: Irsyad Baitus Salam, 1996

Jalal, Abdul Fatah, Min Ushul al-Tarbiyyah fi al-Islam, Mesir: Daar al-Kutuh al-Misriyah, 1977

Ridho, Rasid, Tafsir al-Mannar, Mesir: Daar al-Mannar, $1373 \mathrm{H}$.

al-Abrasy, M. Athiyah, al-Tarbiyah alIslamiyah, Penerjemah: Bustani A. Goni dkk., Jakarta: Bulan Bintang, 1968

Rusiadi, Metodologi Pembelajaran Agama Islam, Cet. Ke II, Jakarta: Sedaun, 2012

Ridwan, Yayan, Ilmu Pendidikan Islam, Cet. Ke I, Jakarta: Sedaun, 2011

Asari, Hasan, Menyingkap Zaman Keemasan Islam, Bandung: Mizan, 1994

Tim Dosen MPK PAI Untirta, Kajian Tematik Peradaban Islam, Serang: Untirta Press, 2019

Buzan, Toni Brain Child: Cara Pintar Membuat Anak Jadi Pintar, Jakarta: Gramedia, 2005

Ulwan, Abdullah Nasih Tarbiyatul Aulad fil Islam, DJamaludin Miri, Jakarta: Pustaka Amani, 1994

Hawwa, Said, Almustakblash Fii Tarkizatil Anfus, alih bahasa oleh: Ainur Rafiq Shaleh Tahmid, Mensucikan Jiwa: Konsep Tarkiyatun Nafs Terpadu, Jakarta, Robbani Press, 1999

Chittick, William C. Sufism: A short Introduction, diterjemahkan Zaimul, Tasawnf di Mata Kaum Sufi, Bandung, Mizan, 2002

Shihab, M. Quraish, Tafsir Al-Misbbah, Jakarta, Lentera Hati, 2002

Qutub, Sayyid, Tafsir Fi Drilalil Quran, Bairut Lubnan, Ihya Al-Turats Al-Arabi, 1967
al-Razi, Imam Fakh r, Tafsir Al-Kabir, cet. III, jilid IV , Beirut: Dar Ihya Al-Turats Al-Arabi, tth

Taimiyah, Ibnu, Majmu al-Fatawa, Saudi Arabia: Percetakan Mushaf Raja Fahd, $1416 \mathrm{H}$ 